\title{
National Training Program for Comprehensive Community Physicians, Venezuela
}

\author{
Eugenio Radamés Borroto Cruz, MD, DrSc, MS, Ramón Syr Salas Perea, MD, MS
}

\begin{abstract}
Introduction Through the 1990s, wide disparities in health status were recorded in Venezuela, a mirror of poor social conditions, decreasing investment in the public health sector and a health workforce distribution unable to meet population health needs or to staff effective, accessible public health services. Venezuelans' health status deteriorated as a result. In 2003-2004, the Venezuelan government launched Barrio Adentro, a new national public health model aimed at assuring primary health care coverage for the entire population of an estimated 26 million. Cuban physicians staff Barrio Adentro clinics, mainly in poor neighborhoods, until enough Venezuelan physicians can be trained to fill the posts.

Intervention Cuban experience with community-oriented medical education and global health cooperation was drawn upon to develop curriculum and provide faculty for the new National Training Program for Comprehensive Community Physicians, begun in 2005 in cooperation with six Venezuelan universities. The program differs from previous Venezuelan medical education models by adopting a stated goal of training physicians for public service, recruiting students who had no previous opportunity for university-level education, and concentrating the weight of their training on a service- and community-based model of education, relying on practicing physician-tutors.
\end{abstract}

Results Over 20,000 students have been enrolled in three years. The six-year program has been extended to all 24 Venezuelan states, relying mainly on Cuban faculty who are practicing Barrio Adentro doc- tors and who receive postgraduate training in medical education. This "university without walls" has accredited 5,131 Barrio Adentro clinics as teaching institutions; its infrastructure includes other health care delivery facilities plus 855 multipurpose classrooms throughout the country. For the $2006-2007$ academic year, the pass rate was $82 \%$ for first-year students and $94 \%$ for second-year students. Some difficulties persist in student selection, pre-medical preparation, and achieving optimum use of existing resources. Academic, institutional, and external evaluations are ongoing.

Conclusion This is the most ambitious example of scaling up of physician training in a single country. The program has been made possible by considerable political will from the Venezuelan and Cuban governments; by the experience acquired through development of the Cuban health system and medical education programs; by the individual commitment of Cuban curriculum developers and physiciantutors; and by ever-more-organized Venezuelan communities. The size of the undertaking, coupled with significant innovations in curriculum, present challenges. The Venezuelan experience - emphasis on training physicians for a revitalized public health sector, accompanied by a paradigm shift in primary care - warrants attention from the international community in the context of the global shortage of health workers and efforts to achieve a more equitable distribution of health services worldwide.

Keywords: medical education, human resources for health, communitybased medical education, primary care, health equity, Venezuela

\section{INTRODUCTION}

Health Status, Poverty and Human Resources for Health in Venezuela: Through the 1990s, wide disparities in health status were recorded in Venezuela, a mirror of poor social conditions, decreasing investment in the public health sector, and a health workforce distribution that failed to meet population health needs or to staff effective, accessible public health services. From 1980 to 2000 , five new patient care facilities were built in the public health sector, compared to 400 private clinics constructed during the same period. From 1970 to 1996 , government funding for health decreased from $13.3 \%$ of the national budget to $7.89 \%$, the latter representing just $1.73 \%$ of the gross domestic product.[1] In this context, public health institutions offered limited services and did not attempt broad coverage.[2] As a report from the Pan American Health Organization (PAHO) concludes: "Throughout the 1990s, the capability of the public health network to provide health services and resolve health problems became critically insufficient."[1] Venezuelans' health status deteriorated as a result: in 1999, over four million children and adolescents suffered malnutrition, 1.2 million aged $7-14$ years had severe malnutrition; $48.9 \%$ of the population was living in poverty.[3]

That same year, the new Venezuelan Constitution redefined health care as a fundamental right of citizens and a responsibility of government, and mandated establishment of a universal, integrated, decentralized and participatory public health system with full government financing.[4]

However, Venezuela lacked sufficient qualified human resources to fulfill this objective, a reflection of the crisis in human resources for health worldwide, especially in developing countries.[5] In $1999,55 \%$ of physicians worked in the five states (out of 24 ) with the highest per capita income in the country.[1] Approximately half the country's 30,000-35,000 employed physicians were working exclusively in the private sector, while the other half were employed part- to full-time in the public sector. Only 4,000 physicians were practicing in primary care. In the 1990s, Venezuela graduated 1,200-1,500 new doctors annually, with $40-50 \%$ directly entering the private sector, and approximately $10 \%$ leaving the country to practice elsewhere. By 2004 , it was estimated that the country needed 20,000-30,000 new physicians for public service if it was to aspire to universal coverage.[6]

Barrio Adentro, International Cooperation and Community Health: In 2002, when a national strike by the Venezuelan Medical Federation shut down most public outpatient and hospital services, the mayor of Caracas' Libertador municipality tried to recruit physicians for a new program to provide vital medical services in poor neighborhoods, the barrios. Only 50 doctors responded, and of those, 30 refused posts that would locate them within the bar- 
rios.[7] An appeal to the Cuban Embassy in 2003 produced the first Technical Cooperation Agreement in Health between Venezuela and Cuba, providing Cuban physicians to work in these underserved neighborhoods and to help develop the Barrio Adentro ("inside the neighborhood") plan, in consultation with government authorities and local community representatives.

In 2004, the Venezuelan government announced ten policy strategies aimed at eliminating social inequities, poverty and exclusion, including one for increasing the efficiency of a comprehensive, integrated public health system. In this context, Barrio Adentro was extended throughout the country with the main objective of assuring primary health care coverage for the population of an estimated 26 million.[1,8]

Barrio Adentro is based on the principles of the 1978 Alma-Ata Declaration,[9] which established the universal right to health as a global goal and emphasized the fundamental role of primary health care in adequately and equitably meeting population health needs.[10-12] These tenets were reaffirmed in the 2007 Buenos Aires Declaration issued at a 60-nation World Health Organization conference reassessing Alma-Ata.[13] Articulated as a public health strategy, Barrio Adentro is designed to transform the public health system from a fragmented, inadequate, underfunded, and inaccessible model into a universal, community-based, fully funded model of services providing preventive, curative, and rehabilitative care to individuals, families, and communities.

Each Barrio Adentro clinic is staffed by at least one physician and one nurse, and serves 250-350 families in a specific geographic area (Community Health Area). These doctor-nurse teams see patients at the clinic, make home visits, and cooperate with local Health Committees to organize health promotion activities. Clinic physicians may refer patients to a local Comprehensive Medical Diagnostic Center (CMDC) furnished with essential diagnostic equipment, laboratories, and treatment facilities; a Comprehensive Rehabilitation Center (CRC) for physical therapy; a regional High-Tech Medical Center (HTMC) for more complex diagnostic testing and treatment; and to optometry or dental offices (Figure 1). All Barrio Adentro services are free of charge.

\section{Figure 1: Barrio Adentro Infrastructure, 2008}

- Organized in 335 municipalities and 591 Community Health

Areas in all 24 states

- Barrio Adentro Clinics: 6,531

- Comprehensive Medical Diagnostic Centers (CMDC): 420; 106 with surgical facilities

- Comprehensive Rehabilitation Centers (CRC): 502

- High-Tech Medical Centers (HTMC): 18

- Optometry offices: 459

- Dental offices: 1,628, with 3,019 dental chairs

- Physicians: 14,000 , mainly primary care specialists*

- Dentists: $2,900^{*}$

- University-level nurses: $2,500^{*}$

- Technical-level nurses: $1,658^{*}$

- Laboratory, imaging, ophthalmology, and rehabilitation technicians, etc.: $7,500^{*}$

*All personnel listed in Figure 1 are Cuban; additional Venezuelan personnel also participate in the program.

Source: Misión Barrio Adentro. Statistical Report. Caracas: Informática de la Misión Médica Cubana (IMIMEC); 2008.
By 2006 , an estimated $73 \%$ of the Venezuelan population was covered by Barrio Adentro services. From 2004 to 2005, 150.5 million patient visits were carried out through Barrio Adentro, nearly four times the number recorded by traditional outpatient services; $40 \%$ of these were home visits. Detection of major childhood killers such as diarrhea and pneumonia nearly doubled in the same period, while deaths from these conditions substantially decreased. According to a PAHO study, Barrio Adentro has had significant impact on health care throughout Venezuela by increasing access and making service delivery more equitable.[8]

Drawing from the Cuban Experience in Medical Training: In addition to insufficient numbers and problems with motivation and maldistribution, the medical profession in Venezuela was fraught with many difficulties common to other countries, which became more evident as authorities attempted to address population health issues and increase equitable service coverage.[5] In particular, physicians were trained in a curative model of medicine that paid little attention to prevention, the needs of the public health sector, or the population's health in general. Students were traditionally drawn from private high schools, and their medical training was primarily classroom-based with some hospital rotations. They spent little or no time in poor communities, and developing a sense of social responsibility was not an objective of the curriculum. This approach coincided with a highly privatized health care system that catered to the concerns of individual patients. $[2,14]$ In short, social accountability of medical schools was not a working principle.[15]

The situation in Cuba before1959 had been similar, but since the early 1960s, a series of medical education reforms were aimed at meeting the needs of what had become a single, universal public health system offering primary, secondary and tertiary services free of charge.[16] An early exodus of half its doctors left Cuba with a scant 3,000 in 1967;[17] but by 2007 , 72,416 physicians were registered in the country of 11.2 million people.[18]

Over the decades, Cuban medical students were placed in community settings during a successively greater proportion of their six-year training; the biopsychosocial approach melded basic, clinical and population health sciences; health promotion became part of the core curriculum; essential competencies were determined on the basis of the country's priority health problems; and humanistic values were emphasized. These transformations were underpinned by considerable political will on the part of the country's leadership and a constitutional mandate of the right to health care.[19-22]

In the 1980s, with the national introduction of the family medicine model (a physician-nurse team in every neighborhood), Cuban medical students began initiating contact with patients and communities from their first year of training.[16,23-25] By the 1990s, virtually all new medical graduates were required to complete a Comprehensive General Medicine (family medicine) residency before opting for a second specialty, as primary care became the backbone of training. This integrated health system model grounded in primary care was put to the test during Cuba's economic crisis of the 1990s. It is one of the factors 
credited with maintaining, and in some cases improving, critical health indicators under such adverse circumstances, and it is the model adapted for the Cuban contribution to Venezuela's Barrio Adentro program.[26,27] By 2007, Cuban indicators were among the best in the hemisphere, with infant mortality at 5.3 per 1,000 live births and life expectancy at 77 years.[18] Equitable access to health care as a social right and efficient use of resources are recognized as positive features of the Cuban health system. $[26,28,29]$

In addition to training a workforce for domestic health care delivery, Cuba has made international service a cornerstone of its medical profession for the last 45 years: since 1963, over 130,000 Cuban health professionals have volunteered abroad.[30] In June, 2008, 36,770 were serving in 70 countries.[31] Such global health cooperation has provided further experience in human resource training: from 1961 to 2007, the country's medical schools graduated 8,572 physicians from other countries, nearly all from Latin America, the Caribbean and Africa. In 2008, 24,848 students from 108 countries were studying medicine in Cuba in the Latin American Medical School and other programs.[32]

Through bilateral accords, Cuban doctors and educators have also participated in establishing ten medical schools across the globe in Yemen, Guyana, Ethiopia, Guinea Bissau, Uganda, Ghana, Gambia, Equatorial Guinea, Haiti and, most recently, Venezuela.[33]

In Venezuela by 2008, 14,000 Cuban physicians were staffing Barrio Adentro clinics, accompanied mainly by Venezuelan nurses, although a number of Cuban nurses and allied health professionals also participate in the program (Figure 1). Cuban personnel and Barrio Adentro facilities have become essential to assuring the sustainability of the Venezuelan public health system as they provide infrastructure for training the healthcare workforce, particularly physicians.

The objective of this article is to characterize the development and present preliminary results of the National Training Program for Comprehensive Community Physicians in Venezuela.

\section{INTERVENTION}

In early 2005, Venezuelan authorities launched the National Training Program for Comprehensive Community Physicians (NTPCCP). Over 20,000 students are currently enrolled. The NTPCCP differs from previous Venezuelan medical education models by explicitly aiming to train physicians for public service, recruiting students who had no previous opportunity for university-level education, and concentrating their training on a service- and community-based model of education, relying on practicing physician-tutors.

Venezuela's Ministry of Higher Education (MHE) established a National Commission to develop and oversee the NTPCCP, chaired by the Vice Rector of the Colegio Universitario Francisco de Miranda. The commission includes members from the MHE, its Office of University Sector Planning, the Ministry of Health and six Venezuelan universities, plus a team of six Cuban medical educators from Barrio Adentro experienced in curriculum development.
The National Commission was charged with addressing all major aspects of the new program:

1. Goals, principles and general design

2. Institutionalization and organization

(Barrio Adentro University)

3. Student selection and support

4. Curriculum design and competencies

5. Faculty preparation

6. Evaluation

Goals, principles and general design: The program's goal is to educate and train an adequate number of physicians with the competencies and commitment required to guarantee full primary care coverage of Venezuela's population through Barrio Adentro, and provide a pool of graduates for other specialties and responsibilities required by the country's public health system. In this context, the objective - to paraphrase the World Health Organization $(\mathrm{WHO})$ - is to get the right doctors with the right skills in the right place doing the right things to generate improvements in health status and equity.[34]

The principles of the program parallel those of the Cuban family doctor system. The NTPCCP aims to graduate community-based physicians with a solid scientific foundation and the necessary clinical competencies to provide comprehensive medical care through health promotion; disease prevention; treatment and rehabilitation of individuals, families, communities; and to preserve and improve the environment. Their training also motivates and empowers these physicians to work with community residents and to resolve an important and particular set of health problems at the primary level in a medical practice infused with humanistic values, responsibility, and social commitment.[35,36]

The main setting for implementation of the six-year curriculum is the community itself - through academically accredited Barrio Adentro clinics, community-based multipurpose classrooms, and other Barrio Adentro facilities. Faculty in this "university without walls" are Cuban physicians participating in Barrio Adentro who receive pedagogical training and academic accreditation for their teaching role, and are supported by investments in textbooks, classroom models, and digital teaching aids. Students are high school graduates, many from the communities where they will eventually practice.

Institutionalization and organization (Barrio Adentro University): Planning, organization, leadership, monitoring, control and evaluation of the NTPCCP is the responsibility of the National Commission, which integrates the perspectives and activities of the Cuban-led Barrio Adentro National Academic Coordinating Committee and the participating Venezuelan universities, effectively constituting Barrio Adentro University. In each state, the National Commission is supported by Bolivarian Advisory Commissions in Health (BACH), which coordinate the leadership, implementation and development of the program in their respective territories. Each BACH includes representatives of the Ministry of Higher Education, Ministry of Health, Barrio Adentro's state-level coordinating committee, and the Venezuelan university associated with the NTPCCP in the state, as well as representatives from local communities. This organizational pattern is mirrored at the municipal level. The NTPCCP of Barrio Adentro University has been officially accredited by the Bolivarian Republic of Venezuela's National Council of Universities.[37] 
Student selection and support: Through the 1990s, admission to Venezuelan universities was limited. Most slots were filled by graduates of private high schools, leaving over half a million public high school graduates excluded from access to higher education.[14] In recent years, however, the government has instituted several programs to address this social debt by providing free education at various levels, including the NTPCCP.[38]

In April 2005, the Ministry of Higher Education issued a first call in the mass media for applicants to the NTPCCP and received over 35,000 responses.[36] Applications were reviewed by local, state, and national admissions committees. Applicants were interviewed by a representative from the Sucre Mission (a Venezuelan program promoting access to higher education) and a Cuban physician to ascertain motivation and to provide applicants with details of the program: full-time nature, duration, modalities of study, etc. Each applicant was required to present a written recommendation from the Community Health Committee in their locale and to sign an affidavit confirming their commitment to practice in communities-in-need upon graduation.

As a result, 24,000 students were admitted into a four-month premedical bridging course. Some 16,000 students successfully completed this course and began their medical studies in October, 2005.[36] A monthly stipend of 200,000 bolivares was provided (minimum monthly wage in 2006 was 465,000). This is especially important given the large percentage of students from low-income families, marginalized indigenous populations, and poor rural areas.[38,39]

Curriculum design and competencies: The Barrio Adentro National Academic Coordinating Committee developed the NTPCCP curriculum. They drew fundamentally on the curriculum formulated by llizástigui et al.[23,24] in Cuba in the 1980s, based on the social mandate of medical schools to contribute to the promotion, conservation and restoration of population health,[16] which, in turn, determines the type of professionals to be trained, the health problems they should be capable of diagnosing and treating, the professional competencies required, and the educational objectives guiding the process. The Committee also reviewed international literature on the vision, role and curricular design of medical education for the twenty-first century, [5,10,4044] plus the Venezuelan and Cuban experiences and two key international documents: Global Standards for Basic Medical Education of the World Federation for Medical Education[45] and the Global Minimum Essential Requirements in Medical Education of the Institute for International Medical Education.[46]

As a result, the essential elements listed in Figure 2 were identified for the NTPCCP curriculum.

The curriculum design also took into consideration 205 main health problems identified in Venezuela and the competencies required of community physicians to address them, given adequate mandate and appropriate resources. This process yielded an analysis of necessary core competencies, developed in the following areas:

General: communication; professional, ethical, moral and civic attitudes; information analysis and interpretation; independent and
Figure 2: Essential Elements in the NTPCCP Curricular Design

- Ensure focus on medicine that is humanistic, holistic and biopsychosocial.

- Integrate medical care and education, with primary health care as the foundation.

- Identify Barrio Adentro clinics as the main settings for learning, progressively incorporating other institutions and patient care facilities.

- Link students with family and community medicine from their first year of training.

- Develop moral, ethical, civic, and professional values.

- Educate and train by objectives.

- Integrate content of basic biomedical and sociomedical sciences horizontally and vertically.

- Link theory and practice, integrating clinical and basic sciences in curricular units based on main health problems identified.

- Implement a teaching strategy that integrates orientation of learning activities, consolidation of knowledge and skills, and evaluation of learning results.

- Develop new roles for students and teachers: students as active agents, builders of their learning process; teachers as orienters, guides and tutors in the process.

- Structure an evaluation system that integrates academic and licensing evaluations.

- Organize systematic curricular evaluation, using action research methodology, to identify and adjust problem areas; progressively evaluate program impact.

- Ensure effective bridging and updating of knowledge in the basic sciences, Spanish language, and study skills through the premedical course.

creative problem-solving and decision-making; social interaction; teamwork; and legal responsibility.

Patient care: approach to individual and collective health problems using clinical and epidemiological methods; health promotion and disease prevention; diagnosis; therapeutic and rehabilitation management; environmental health.

Educational: didactic, methodological, technological competencies; social education; continuous independent study.

Administration and management: social participation; administrative - planning, organization, management and control; selfevaluation.

Some 60 Cuban medical school professors with considerable experience in various disciplines of biomedical and sociomedical sciences designed the curricular units and academic calendars. A six-year curriculum was developed (Figure 3).

The discipline of Human Morphophysiology takes an inter- and transdisciplinary approach, integrating basic biomedical sciences such as human anatomy, normal histology, embryology, normal and pathologic physiology, cellular and molecular biology, genetics and immunology (Morphophysiology I, II, III in first year and IV in second year). Morphophysiopathology (I and II in second year) takes a transdisciplinary approach to basic sciences related to clinical practice: clinical laboratory, imaging, parasitology, microbiology, anatomic pathology, genetics, and immunology, as well as the main immune, hemodynamic, genetic and neoplasic pathological processes. 
Figure 3: Curricular Units of the National Training Program for Comprehensive Community Physicians (NTPCCP), Venezuela*

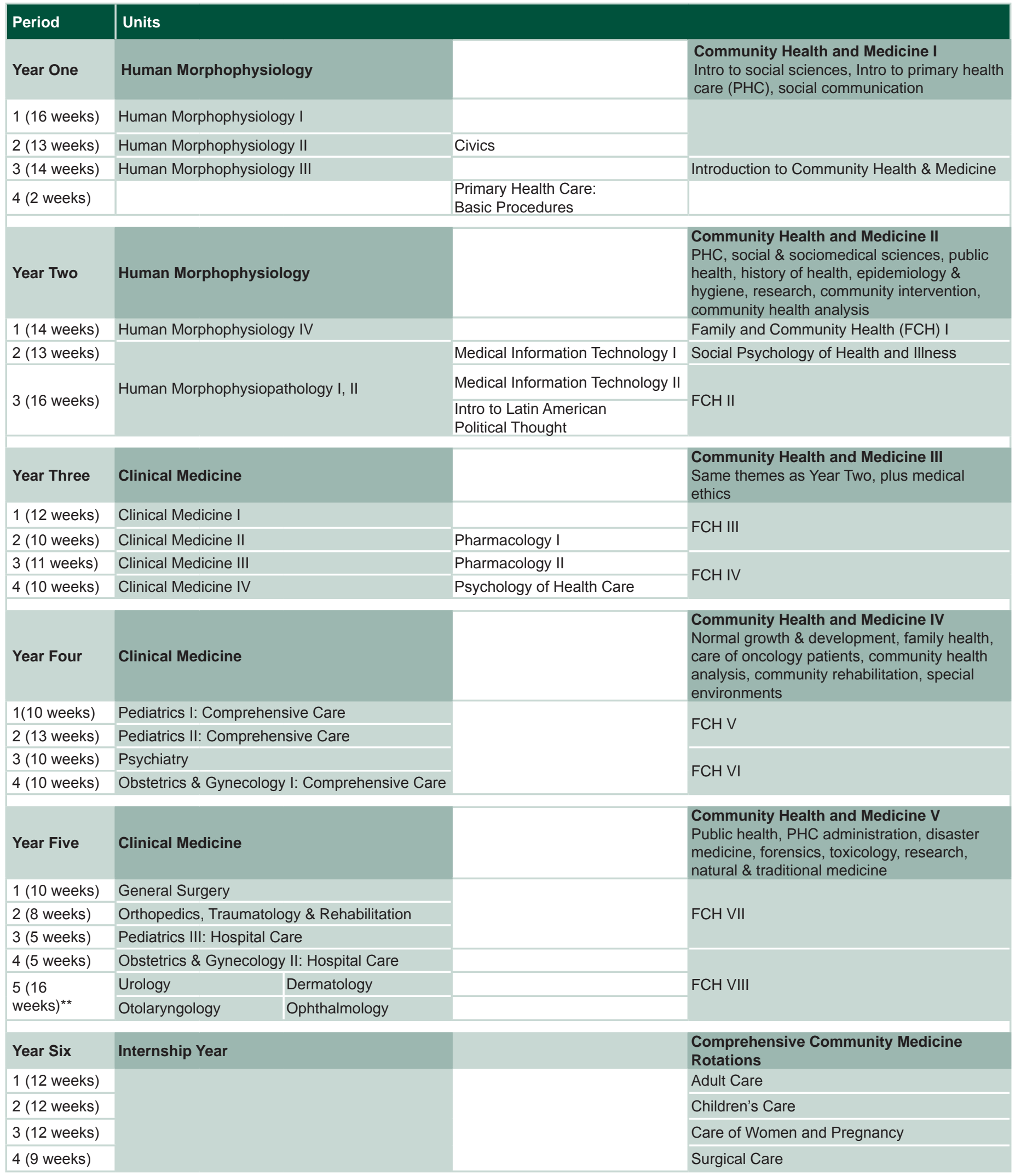

*Does not include elective periods.

**In rotations of four weeks each.

Source: Diaz, P. Barrio Adentro National Academic Coordinating Committee, August 2008. 
The socio-medical sciences are also taught beginning in the first year, in the discipline of Community Health and Medicine. Medical Information Technology covers data collection, treatment and reporting, as well as essential elements of descriptive and health statistics. Introduction to Latin American Political Thought provides context for medical education and practice. From the third year through internship, the program is structured in two broad areas: 1) Ambulatory patient care in the Community Health Area; and 2) Inpatient care.

This approach relies on problem-based individual and group learning, guiding students through themes (orientation, consolidation, and evaluation of knowledge and skills gained) along a continuum from simulation towards real practice situations. A typical academic week for students through the third year combines time in the multi-purpose classroom (together with students and faculty from the surrounding Community Health Area), the Barrio Adentro clinic, and the community itself (Figure 4).

Faculty preparation: The 60 professors mentioned above also developed a national plan to adequately prepare faculty selected from Cuban specialists (primarily in family medicine) working in Barrio Adentro, which contemplates three aspects:

1. Individual study of the biomedical, clinical, and sociomedical content of each year of the medical education program.[47]

2. Basic preparation in medical education and pedagogy, through two certificate courses and subsequent master's program.

3. Systematic methodological study to develop specific teaching activities and evaluate faculty preparedness.

The main Cuban academic directors of the NTPCCP at the municipal, state, and national level are also enrolled in the master's program in medical education sponsored by Cuba's National School of Public Health.

Evaluation: NTPCCP curriculum evaluations include three basic components:

1. Academic evaluation for each subject taught, including a global assessment of student performance, based on nationally standardized theoretical and practical (clinical) final exams formulated by the National Academic Coordinating Committee's team of experts. Systematic statistical control of academic results is maintained, and $30 \%$ of test papers for each exam receive a second review.
2. Institutional evaluation through: a) visits to academic settings by methodology advisors with ten or more years experience in medical education, and who participated in NTPCCP curriculum development; b) continuing medical education for faculty, including evaluation; and c) academic and attendance assessments of students in their fourth, eighth and eleventh weeks of various courses.

3. External evaluation consisting of pedagogical research projects by curriculum designers, applying evaluation instruments to $50 \%$ of students and $70 \%$ of faculty to assess quality of curriculum application and satisfaction. These include surprise exams and visits to academic settings and document archives.[48]

\section{PRELIMINARY RESULTS}

A new paradigm of medical education has been introduced in Venezuela to train comprehensive community physicians capable of addressing the majority of the population's health problems at the primary care level. Barrio Adentro University's National Training Program for Comprehensive Community Physicians is underway in all 24 states of the country, with a May 2008 enrollment of 21,902 students: 5,118 in first year; 6,209 in second year; 10,575 in third year; and approximately 5,000 in the pre-medical course. For the 2006-2007 academic year, the pass rate was $82 \%$ for first-year students and $94 \%$ for second-year students. A total of 4,503 students $(26 \%$ of initial enrollment) have dropped out of the program since its inception, mainly due to poor academic performance.

A total of 6,715 faculty - primary care specialists who also staff Barrio Adentro clinics - teach in the program; 4,602 (68.5\%) of them have attained the academic rank of at least Instructor or Assistant Professor, having met requirements established by Cuba's Ministry of Higher Education. An 18 to 24-month master's program in medical education has been implemented through Cuba's $\mathrm{Na}$ tional School of Public Health; 126 faculty and program directors at various levels have obtained MS degrees.[49] Progressively more Venezuelan faculty have joined the program, although the number is still relatively small.

The state-level Bolivarian Advisory Commissions in Health $(\mathrm{BACH})$ have accredited 5,131 Barrio Adentro clinics as teaching institutions, according to norms that consider number and level of faculty, available physical infrastructure and resources, audiovisual and digital teaching aids, and proximity of one of the 855 multipurpose classrooms in the country.

Weekly visits to teaching sites by the Academic Committee's methodology group have been systematized for the purpose of

Figure 4: Typical Academic Week Years 1-3, National Training Program for Comprehensive Community Physicians (NTPCCP)

\begin{tabular}{|c|c|c|c|c|c|c|}
\hline Session & Monday & Tuesday & Wednesday & Thursday & Friday & Saturday \\
\hline Morning & $\begin{array}{c}\text { CSBL, } \\
\text { BA Clinic }\end{array}$ & $\begin{array}{c}\text { CSBL, } \\
\text { BA Clinic }\end{array}$ & $\begin{array}{c}\text { CSBL, } \\
\text { BA Clinic }\end{array}$ & $\begin{array}{c}\text { CSBL, } \\
\text { BA Clinic }\end{array}$ & $\begin{array}{c}\text { CSBL, } \\
\text { BA Clinic }\end{array}$ & Consultation, MC \\
Afternoon & $\begin{array}{c}\text { Evaluation Activity } \\
\text { (previous theme), MC }\end{array}$ & $\begin{array}{c}\text { Orientation Activity } \\
\text { (new theme), MC }\end{array}$ & $\begin{array}{c}\text { CSBL } \\
\text { (in the community) }\end{array}$ & $\begin{array}{c}\text { Consolidation of knowledge } \\
\text { (current them), MC }\end{array}$ & $\begin{array}{c}\text { CSBL } \\
\text { (in the community) }\end{array}$ \\
\hline Evening & & & Independent Study &
\end{tabular}

CSBL: community- and service-based learning.

BA Clinic: Barrio Adentro Clinic

MC: multipurpose classroom

Source: Diaz, P. Barrio Adentro National Academic Coordinating Committee, August 2008. 
supervision, control and orientation, as have semi-annual visits to each Community Health Area by a multidisciplinary team from the National Academic Coordinating Committee itself. Results are analyzed at the municipal, state and national level, the latter by the NTPCCP National Commission.

An action research study by the National Academic Coordinating Committee,[50] carried out in March-April 2008 in all 24 states, involved 124 faculty teams from 108 Community Health Areas (18.4\% of total), with participation by $100 \%$ of students and faculty present at the time of the researchers' visit. As a result, 5,739 persons were surveyed: 1,199 faculty (15\% of total faculty); 2,552 students (12\%); and 1,988 community residents (1 per 10,000 population). A total of 3,871 persons participated in group interviews (1,277 faculty and 2,594 students).

Results from the study corroborated existence of minimum essential infrastructure to support the program, as well as consistent implementation of certificate courses and the master's program for faculty and program directors.

Although the detailed methodology is not within the scope of this paper, it should be noted that qualitative portions of results revealed generalized student satisfaction, a ratified commitment to practice in underserved communities, as well as positive NTPCCP contribution to patient satisfaction. Difficulties were revealed in the following areas:

- All faculty did not achieve adequate integration of content in the various subjects, as prescribed by the curricular guidelines.

- Student selection, and the quality and rigor of the pre-medical course, continued to be uneven and therefore problematic.

- Potential of the community- and service-based learning opportunities was not fully realized, and insufficient use was made of diagnostic equipment in Community Health Area institutions.

\section{DISCUSSION}

The NTPCCP constitutes the design, development, and implementation of the most ambitious scaling-up of education of doctors for public service in a single country, based on a significant paradigm shift. This has been made possible by considerable political will on the part of the Venezuelan and Cuban governments, which have facilitated the necessary investments and human resources; by the individual commitment of Cuban curriculum developers and physician-tutors; and by the ever-more-organized Venezuelan communities.

The program has also been made possible by four decades of Cuban experience in medical education for public health with a primary care focus and within a system based on a universal, equitable health service delivery model. Finally, the program has rested on the integration of medical education into Barrio Adentro comprehensive public health services, and of the Barrio Adentro delivery model into the fabric of social programs in place in Venezuela today. No doubt such an array of factors must be present for this experience to be replicable in another setting.

At the same time, the sheer size of the undertaking, coupled with innovations that have gone beyond reforms hitherto in place either in Venezuela or Cuba, present significant challenges to the program's successful outcomes. These challenges include:

- student selection and retention, given the educational and economic obstacles faced by the mainly low-income, marginalized student population;

- use of family medicine specialists as teachers, which has required an extra effort organizationally, academically and individually, to assure assimilation and communication of new pedagogical concepts (hence the early difficulty in integrating content);

- the fact that Barrio Adentro itself is still being expanded and articulated as part of the health system reform, reflected in uneven development in different places, changing infrastructure, etc.; and

- growing demands by communities and patients.

The challenge of quality assurance is a permanent one, not only in traditional academic terms, but also with regard to formulating relevant standards and instruments for measuring the new program's success against population health goals, as well as for developing innovative tools to correct the course where necessary. The action research study in early 2008 offers one example of efforts in this direction.

Any final measure of the program's success - its impact on health services and their accessibility, on the health status of the population, and on the graduates' future commitment to a career in public service - is still several years away. Documentation and assessment at every stage are required to reveal the outcomes for Venezuela as well as the program's full range of lessons for other countries.

If the goal of "Health for All" is to be reclaimed, a more equitable distribution of health services and health professionals is essential. From this perspective, the Venezuelan experience - emphasis on training physicians for a revitalized public health sector, accompanied by a paradigm shift in medical education and primary care - warrants particular attention from the international community. - $-1 /$ -

\section{REFERENCES}

1. Modelos de atención en salud en Venezuela y exclusión social. In: Organización Panamericana de la Salud. Barrio Adentro: Derecho a la salud e inclusión social en Venezuela. Caracas: OPS/ OMS para Venezuela; 2006. p. 5-19.

2. Rincón MT, Rodríguez I. Consideraciones generales sobre la política y gestión de la salud en Venezuela (1900-2003). FERMENTUM. 2004 Sept-Dec;14(41):503-32.
3. Reginfo AM. Reflexiones sobre el Problema de Salud en Venezuela. Caracas: Gráficos Tao SA; 2005.

4. República Bolivariana de Venezuela. Constitución de la República Bolivariana de Venezuela 1999, Artículos 83-86. Caracas: Imprenta Nacional; 2000.

5. The President and Fellows of Harvard Collage. Human Resources for Health. Overcoming the crisis. Joint Learning Initiative. Cambridge: Harvard University Press; 2004.

6. Mauricio Vega (representative of the Venezuelan Ministry of Health and Social Development in the Barrio Adentro National Academic Coordinating Committee), interview by Gail Reed, 2006 Feb 6.

7. Origen de Barrio Adentro y participación ciudadana. In: Organización Panamericana de la Salud. Barrio Adentro: Derecho a la salud e inclusión 
social en Venezuela. Caracas: OPS/OMS para Venezuela; 2006. p. 21-43.

8. Impacto de Barrio Adentro. In: Organización Panamericana de la Salud. Barrio Adentro: Derecho a la salud e inclusión social en Venezuela. Caracas: OPS/OMS para Venezuela; 2006. p. 83-119.

9. Alma Ata Conferencia Internacional sobre Atención Primaria de Salud. Declaración Final, 12 septiembre de 1978. In: Bibliografía del Diplomado I de Dirección en Salud. [CD-ROM]. Havana: GIESP ENSAP; 2004.

10. Mahler HT. Algunas reflexiones sobre liderazgo y equidad en salud. In: González García G et al. Hacia un cuidado integral de la salud para la equidad: De Alma Ata a la Declaración del Milenio. Conferencia Internacional de Salud para el Desarrollo: "Derechos, hechos y realidades". $1^{\text {a }}$ ed. Rossen M (ed). Buenos Aires: Ministerio de Salud de la Nación; 2007. p. 98-103.

11. Borroto Cruz R, Lemus Lago ER, Aneiros-Riba R. Atención Primaria de Salud y Medicina Familiar. Biblioteca de Medicina Volumen XXXIV. La Paz: Universidad Mayor de San Andrés; 1998

12. González García G. Prólogo. In: González García $G$ et al. Hacia un cuidado integral de la salud para la equidad: De Alma Ata a la Declaración del Milenio. Conferencia Internacional de Salud para el Desarrollo: "Derechos, hechos y realidades". $1^{\text {a }}$ ed. Rossen M (ed). Buenos Aires: Ministerio de Salud de la Nación; 2007.

13. Declaración de Buenos Aires 30-15. Hacia una Estrategia de Salud para la Equidad, basada en la Atención Primaria. In: González García G et al. Hacia un cuidado integral de la salud para la equidad: De Alma Ata a la Declaración del Milenio. Conferencia Internacional de Salud para el Desarrollo: "Derechos, hechos y realidades". $1^{\text {a }}$ ed. Rossen M (ed). Buenos Aires: Ministerio de Salud de la Nación; 2007.

14. Samuel Moncada (Minister of Higher Education of Venezuela), interview by Gail Reed, 2006 Feb 6.

15. Boelen C, Heck JE. Defining and measuring the social accountability of medical schools. Geneva: World Health Organization; 1995.

16. Fernández Sacasas JA. Educación médica superior: realidades y perspectivas a las puertas del nuevo siglo. Centro Nacional de Perfeccionamiento Médico. Havana: 1999

17. Centro Nacional de Información de Ciencias Médicas. Emigración Médica. Havana: 1968.

18. Anuario estadístico de salud 2007. Ministry of Public Health, National Statistics Division; Havana: 2008.

19. Escuela Nacional de Salud Pública. Colectivo de autores. El Pensamiento de Fidel en la Salud y la Medicina Familiar Cubana; 2003. In: Bibliografía del Diplomado I de Dirección en Salud. [CD-ROM]. Havana: GIESP ENSAP; 2004.

20. Castro Ruz F. Discurso pronunciado en el acto conmemorativo del 40 Aniversario del ICBP "Victoria de Girón", 17 Aug 2002 [monograph on the Internet]. [cited 2006 Jun 10]. Available from: http://www.cuba.cu/gobierno/discursos

21. Castro Ruz, F. Reflexiones del Comandante en Jefe. Lula (cuarta y última parte). 1 Feb 2008 [monograph on the Internet]. [cited 2008 Feb 23]. Available from: http://www.granma.cubaweb.cu/2008/02/01/index.html.

22. Constitución de la República de Cuba. Artículo 50 [monograph on the Internet]. Havana: Government of Cuba; 1992 [cited 2008 Mar 12]. Available from: www.Cuba.cu/gobierno/cuba.htm.

23. Ilizástigui F, Calvo I, Douglas R. El Programa Director de la Medicina General Integral para el Médico General Básico (pamphlet). Havana: Ministry of Public Health; 1985

24. Ilizástigui Dupuy F, Douglas Pedroso R. Formación del médico general básico en Cuba. Educ Med Salud. 1991;25(2):189-205

25. Jardines Méndez JB et al. Cuba: recursos humanos en la atención primaria de salud y su estrategia de desarrollo. Educ Med Salud. 1993;27(3):145-159.

26. Spiegel JM, Yassi A. Lessons from the margins of globalization: appreciating the $\mathrm{Cu}$ ban health paradox. J Public Health Policy. 2004;25(1):85-110.

27. Reed G. Challenges for Cuba's family doctorand-nurse program. MEDICC Review [serial on the Internet]. 2000;2(3) [cited 2008 Apr 15]. Available from: http://www.medicc.org/publications/medicc_review/ll/primary/sloframe.html.

28. United Nations Population Fund (UNFPA). El Estado de la Población Mundial, 2002. Población, pobreza y oportunidades [monograph on the Internet]. [cited 2006 Jul 4]. Available from: http:// www.unfpa.org/swp/2002/swpman spa.htm.

29. Centro de Investigaciones de la Economía Mundial (CIEM). Investigación sobre desarrollo humano y equidad en Cuba 1999 [monograph on the Internet]. Havana: CIEM; 1999 [cited 2008Aug 12]. Available from: http://www.undp. org.cu/ldh99.html.

30. Balaguer Cabrera JR, Address on the 45th anniversary of Cuban international cooperation in health; 2008 May 26; Havana, Cuba.

31. Gorry C. Cuban health cooperation turns 45 . MEDICC Review. 2008;10(3):44-47.

32. Government of Cuba, Ministry of Foreign Relations. Datos estadísticos [working paper]. Havana: 2008 March19.

33. Government of Cuba, Ministry of Public Health. Unidad Central de Cooperación Médica [working paper]. Havana; 2007.

34. Working together for health. World health report 2006. Geneva: World Health Organization; 2006.

35. Permanencia de Barrio Adentro y formación de recursos humanos. In: Organización Panamericana de la Salud. Barrio Adentro: Derecho a la salud e inclusión social en Venezuela. Caracas: OPS/OMS para Venezuela; 2006. p. 71-81.

36. Molina JR. Sinopsis del proceso de selección de los estudiantes para el programa nacional de formación de medicina integral comunitaria [memo to the authors]. $2008 \mathrm{Apr} 4$.

37. Bolivarian Republic of Venezuela National Council of Universities. Permanent Secretariat. Resolución № 190, Caracas, 2007 Dec 3. Gaceta Oficial. Año CXXXV, Mes III, No. 38.8. Caracas: 2007 Dec 17

38. Desarrollo de nuevas redes en el sistema público nacional de salud. In: Organización Panamericana de la Salud. Barrio Adentro: Derecho a la salud e inclusión social en Venezuela. Caracas: OPS/OMS para Venezuela; 2006. p. 45-69.

39. Baños J, Baños JL. La salud más allá de Barrio Adentro. Granma. 2005 Jun 22;3.

40. Cornet Calveras A. Nuevos planteamientos didácticos: ¿Al innovar en docencia, mejoramos el aprendizaje? Educación Médica (Barcelona) [serial on the Internet]. 2006 Sep [cited 2007 Oct 5];8 Suppl. 1. Available from: http://scielo.isciii.es/scielo.php?script/=sci_ issue\&pid=1575-1813\&lng es\&nrm=iso

41. Rozman C. Reflexiones sobre la universidad en el ámbito biomédico. Educación Médica (BarceIona) [serial on the Internet]. $2005 \mathrm{Dec}$. [cited 2007 Oct 5];8(4). Available from: http://scielo. isciii.es/scielo.php?script/=sci_issue\&pid=15751813\&Ing_es\&nrm=iso
42. Escayola Maranges AM. A las puertas del cambio en la Formación Universitaria. Educación Médica (Barcelona) [serial on the Internet]. 2005 June. [cited 2007 Oct 5];8(2). Available from: http://scielo.isciii.es/scielo.php?script/=sci_ issue\&pid=1575-1813\&lng_es\&nrm=iso

43. Cooke M, Irby DM, Sullivan W, Ludmerer KM. American medical education 100 years after the Flexner report. $N$ Engl J Med. 2006;355(13):1339-44.

44. Pan American Health Organization (PAHO). Regional consultation on human resources in health: critical challenges. Proceedings of the Regional Meeting of the Observatory of Human Resources in Health; 2005 Oct 4-7; Toronto, Canada. Washington DC: PAHO; 2005.

45. Federación Mundial para la Educación Médica. Informe del Grupo de Trabajo para la Definición de Estándares Internacionales para la Educación Médica de Pregrado. Copenhagen, 1999 Oct 14-16. Educ. Méd. 2000;3(4):158-169.

46. Instituto para la Educación Médica Internacional (IIME). Requisitos globales mínimos esenciales en educación médica. Educación Médica (Barcelona) [serial on the Internet]. 2003 Jul-Set. [cited 2008 Apr 24];6 Suppl.2. Available from: http://scielo.isciii.es/scielo.php?script/=sci_ issue\&pid=1575-1813\&lng_es\&nrm=iso

47. Tomé López O, Nogueira Sotolongo M. Identificación de necesidades de aprendizaje en profesores del programa de formación del médico integral comunitario. Rev Cubana Med Super [serial on the Internet]. 2007 Oct-Dec 21(4). [cited 2008 Aug 24]. Available from: http://bvs. sld.cu/revistas/ems/vol21 4 07/ems04407.pdf

48. Díaz P. Barrio Adentro National Academic Coordinating Committee [working paper]. Caracas: 2008 Aug 3

49. Nogueiras Sotolongo M. National Coordinating Group for the Master's Degree Program in Medical Education, Venezuela [personal communication]. 2008 Aug 5 .

50. Salas Perea RS. Extracto resumen de la investigación sobre la caracterización del desarrollo del proceso formativo en el programa nacional de formación del médico integral comunitario en la República Bolivariana de Venezuela, 2008 [memo to Barrio Adentro National Academic Coordinator]. Caracas: 2008 Aug 3.

\section{THE AUTHORS}

Eugenio Radamés Borroto Cruz (Corresponding Author: radamesborroto@ yahoo.es), specialist in health administration and medical education. Director and full professor, National School of Public Health, Havana, Cuba. Barrio Adentro National Academic Coordinator, Caracas, Venezuela.

Ramón Syr Salas Perea, specialist in general surgery and public health, full professor of public health and medical education. Consulting professor, National School of Public Health, Havana, Cuba; member, Barrio Adentro National Academic Coordinating Committee, Caracas.

Submitted: May 13, 2008

Approved for publication: September 20, 2008 